\title{
Haematological Alterations in Kuroiler Chicks Exposed to Cadmium Acetate
}

\author{
Anju ${ }^{1}$, Girima Nagda ${ }^{1, *}$, D. K. Chauhan ${ }^{2}$ \\ ${ }^{1}$ Department of Zoology, University College of Science, Mohanlal Sukhadia University, India \\ ${ }^{2}$ Department of Zoology, Chaudhary Charan Singh University, India
}

Received February 6, 2020; Revised April 8, 2020; Accepted April 19, 2020

Copyright $\subseteq 2020$ by authors, all rights reserved. Authors agree that this article remains permanently open access under the terms of the Creative Commons Attribution License 4.0 International License

\begin{abstract}
The current study was designed to evaluate the effect of cadmium on the haematological profile of Kuroiler chicks. Kuroiler chick is a diseases resistance hybrid variety developed in India and is more promising than broilers etc., in terms of both the protein content of the meat and the benefits it has on the poultry industry. 10 days old Kuroiler chickens were exposed to a single sub lethal dose $(7 \mathrm{mg} / \mathrm{kg}$ body weight) of cadmium acetate and different blood parameters were evaluated after 20 and 40 days of exposure. The different parameters were analyzed and calculated using standard methods and formula. It was noted that cadmium has an effect on all the blood parameters. Treated groups revealed significant suppression of total erythrocyte count, haemoglobin, packed cell volume, mean corpuscular haemoglobin concentration and neutrophils. The total leucocyte count, mean corpuscular haemoglobin, mean corpuscular volume, lymphocytes, eosinophils, monocytes and basophils were found to be increased in treated groups. The drastic alterations in studied parameters indicated that cadmium has long term effect on the blood profile of chicken and thus ultimately affect the health status of the chick, the quality of meat and also hampers the poultry industry.
\end{abstract}

Keywords Cadmium, Erythrocytes, Haematological Profile, Haemoglobin, Kuroiler Chick, Leucocytes

\section{Introduction}

Poultry is one of the most important and fastest growing segments of the agriculture sector in India. India is world's fifth largest egg producer and the eighteenth largest producer of broilers [1]. Indian poultry has shown spectacular progress transforming itself from backyard farming to a dynamic and sophisticated agro-based industry. Poultry industry is advancing by improvement of genetic potential of new fowls' strains [2] to provide the high quality with low cost protein requirements of the human population worldwide. A large chunk of Indian population consumes poultry eggs and broiler chicken; therefore, the quality of meat and eggs should be maintained.

The Kuroiler is a hybrid of chicken developed in India. Introduced in the early 1990's this breed was created by Vinod Kapur of Kegg Farms Private, Ltd., and the name is a portmanteau of Kegg and Broiler. Kuroiler are derived from crossing either coloured broiler males with Rhode Island Red females, or White Leghorn males crossed with female Rhode Island Red. Kuroiler, a dual purpose breed producing meat and egg, can live on a diet of kitchen and agricultural waste, and produce around 150 eggs per year whereas native Indian hens lay only 40 eggs per year. Due to its unique genetic features, the Kuroiler is resistance to diseases and is a potential bio convertor of no cost agricultural, household and natural waste into human protein food and substantial incomes for rural household.

Kuroiler have been become popular in rural areas in India, including Uttar Pradesh, Jharkhand, West Bengal, Mizoram, Chhattisgarh, Meghalaya and Uttarakhand. The Govt. of Uganda had imported Kuroiler hatching eggs and the Kuroilers outperformed the indigenous birds in growth rate, body weight, eggs production, egg size and hatchability which transforms to a $133 \%$ increase in meat production, $462 \%$ increase in egg production and a $341 \%$ increase in income for rural poultry farmers [3]. Thus, Kuroilers seem to empower the poultry industry as well as the quality of meat.

Heavy metals are one of the most common forms of anthropogenic pollutants in the environment thus threatening human and animals' health through environmental and occupational exposure. Cadmium is an environmental pollutant and can be considered as the most toxic heavy metals [4]. As cadmium is non-biodegradable it is found widely in nature and present in air, all soils and aquatic systems [5, 6]. Natural and human related activities are responsible for cadmium pollution [7, 8]. Raised 
concentration of cadmium in soil may be found as a result of industrial activities (sewage, phosphate fertilizers and pesticides) containing high concentrations of cadmium [9].

Under normal conditions, the intake of cadmium depends on the concentration in the sources as air, water, and land. Cadmium results in the formation of reactive oxygen species [10] causes various adverse effects such as disturbances of enzymes function [11], the enhancement of lipid peroxidation [12], nephrotoxicity [13], immunotoxicity [14], carcinogenesis and oxidative DNA damage [15].

Cadmium exposure in animals occurs due to inhalation of polluted air, ingestion of polluted food and drinking of polluted water [16-18]. It is absorbed from gastrointestinal tract to blood and is taken up from the blood into tissues. Reduced feed intake resulting in weight loss, decreased $\mathrm{RBC}$ and $\mathrm{Hb}$ values and anaemia occur in cadmium exposed animals $[19,20]$. Anaemia is a major hematotoxic effect following long term exposure to cadmium in man $[21,22]$ and in laboratory animals $[23,24]$.

The importance of haematological biochemistry, population genetics and medical anthropology is well established. Recent speculations have proved that they may be used as valuable indicators of disease or stress in animals [25]. Biochemical profiles of blood can provide important information about the internal environment of the organism [26]. Blood parameters are probably the more rapid and detectable variations under stress and are fuel in assessing the health condition [27]. Investigation of haematological parameters is necessary for clinical diagnosis of a disease and pathological condition [28].

Measurement of haematological parameters provides valuable information and is routinely used in human and animal medicines, but unfortunately due to lack of information, blood profile has not been widely used in avian medicine [29, 30]. Several factors including physiological [31] and environmental conditions [32, 33], diet contents [34, 35] water and feed restriction [36-38], fasting [39], age [40-42] and administration of metals [43-44] affect the blood profiles of healthy birds.

WHO recommends the use of blood parameters for medical and nutritional assessment [45-46]. Exposure of cadmium alters different blood parameters, affects the body weight and induces immunopathological changes in thymus [47-49] thus directly affecting the health status. Therefore, investigating the effects of the administration of cadmium is necessary.

Thus the main objective of the present study was to analyze the haematological changes in Kuroiler chick exposed to cadmium acetate to give an insight of the health status of the chicks as well as the quality of meat.

\section{Materials and Methods}

\subsection{Selection and Maintenance of Experimental Birds}

Newly hatched Kruoiler chicks were procured from
Salim hatchery Meerut. Before experimentation the chicks were housed in clean wood and steel cages in animal house and acclimatized to laboratory conditions (temp. $36 \pm 2{ }^{\circ} \mathrm{C}$, light: dark period 18h: $6 \mathrm{~h}$ period). They were fed on formulated chicks feed (Hindustan poultry feed ltd. Meerut India) and water ad libitum. The feeding was stopped $24 \mathrm{~h}$ before commencement of experiments to avoid metabolic variations due to diet.

\subsection{Chemicals}

Cadmium acetate was obtained from BDH, India Ltd., Mumbai. All other chemicals and solvents used were of analytical grade.

\subsection{Dose Selection}

\subsubsection{Determination of Lethal Dose $50\left(\mathrm{LD}_{50}\right)$}

Preliminary toxicity test was conducted under laboratory condition to determine the $\mathrm{LD}_{50}$ value for $72 \mathrm{~h}$ of cadmium by the standard method. Stock solution of the metal cadmium was prepared by simple dilution techniques. The concentration of cadmium below $30 \mathrm{mg} / 100 \mathrm{ml} / \mathrm{kg}$ body weight did not cause any mortality and the mortality rate increased with increase in toxicant dose. The mortality was $100 \%$ after $78 \mathrm{mg} / \mathrm{kg}$ body weight. The percent mortality and probit mortality were statistically analyzed by the probit method of Finney [50] to calculate $\mathrm{LD}_{50}$ value.

The $72 \mathrm{~h} \mathrm{LD}_{50}$ values obtained were: - $70 \mathrm{mg} / 100 \mathrm{ml} / \mathrm{kg}$ body weight.

\subsubsection{Sub Lethal Dose Selected for Experiment}

$1 / 10$ concentration of $72 \mathrm{~h}$ LD50 values were selected as sub lethal concentration i.e., $7 \mathrm{mg} / 100 \mathrm{ml} / \mathrm{kg}$ body weight.

\subsubsection{Dose Schedule}

Single dose was administered via oral gavage in 10 days old chicks. The post- mortem examination was done after 20 and 40 days as per the protocol given.

\subsection{Experimental Design}

The 10 days old acclimatized chicks were divided into four groups with 6 to 8 chicks in each as shown in table 1 .

Table 1. Table showing different experimental groups and nomenclature

\begin{tabular}{|c|c|c|}
\hline Group & Name & $\begin{array}{c}\text { Post-mortem } \\
\text { examination }\end{array}$ \\
\hline Group I A & Control Group (C-20) & After 20 days \\
\hline Group I B & $\begin{array}{c}\text { Cadmium treated group } \\
(\text { Cd- 20) }\end{array}$ & 20 days post treatment \\
\hline Group II A & Control Group (C-40) & After 40 days \\
\hline Group II B & $\begin{array}{c}\text { Cadmium treated group } \\
(\mathrm{Cd}-40)\end{array}$ & 40 days post treatment \\
\hline
\end{tabular}

After the decided experimental duration of different groups blood was collected from the heart of chicks and was analyzed for the various haematological parameters as in table 2 . 
Table 2. Table showing the various haematological parameters studied, their methodologies, formula used for calculation and the units in which the results are expressed

\begin{tabular}{|c|c|c|c|c|}
\hline $\begin{array}{l}\text { S. } \\
\text { No. }\end{array}$ & Parameter studied & Methodology used & Formula used & Units \\
\hline 1 & $\begin{array}{c}\text { Total Erythrocyte Count } \\
\text { (TEC) }\end{array}$ & $\begin{array}{c}\text { Neubaur's haemocytometer } \\
\text { chamber method [51] }\end{array}$ & No. of $\mathrm{RBC}$ counted $\times 10000$ & Millions $/ \mathrm{mm}^{3}$ \\
\hline 2 & $\begin{array}{l}\text { Total Leukocytes Cells } \\
\text { (TLC) }\end{array}$ & $\begin{array}{c}\text { Neubaur's haemocytometer } \\
\text { chamber method [51] }\end{array}$ & No. of RBC counted $\times 50$ & $\mathrm{~mm}^{3}$ \\
\hline 3 & Haemoglobin $(\mathrm{Hb})$ & Acid haematin method [52] & $\begin{array}{l}\text { Dilution of haemoglobin was read in } \\
\text { terms of gram percentage }\end{array}$ & $\begin{array}{l}\text { grams per } 100 \mathrm{ml} \text { of } \\
\text { blood }(\mathrm{gm} / \mathrm{dl})\end{array}$ \\
\hline 4 & Packed Cell Volume (PCV) & $\begin{array}{c}\text { Wintrobe's haemocrit tube } \\
{[53]}\end{array}$ & $\begin{array}{l}\text { The column of red blood in the Wintrobe's } \\
\text { tube was read as percentage }\end{array}$ & $\%$ \\
\hline \multirow{2}{*}{5} & \multirow{2}{*}{$\begin{array}{c}\text { Mean Corpuscular } \\
\text { Haemoglobin }(\mathrm{MCH})\end{array}$} & & Haemoglobin in $\mathrm{gm} / \mathrm{d} 1 \mathrm{X}$ & \multirow{2}{*}{ Pictograms (pg) } \\
\hline & & & $10 \mathrm{RBC}$ in millions & \\
\hline \multirow{2}{*}{6} & \multirow{2}{*}{$\begin{array}{l}\text { Mean Corpuscular Volume } \\
\text { (MCV) }\end{array}$} & & PCV $(\%) \times 10$ & \multirow{2}{*}{ Femtolitre (fl) } \\
\hline & & & $\overline{\mathrm{RBC} \text { in millions }}$ & \\
\hline \multirow{2}{*}{7} & \multirow{2}{*}{$\begin{array}{c}\text { Mean Corpuscular } \\
\text { Haemoglobin Concentration } \\
(\mathrm{MCHC})\end{array}$} & & Haemoglobin in gm/d1 X & \multirow{2}{*}{$\mathrm{Gram} / \mathrm{dl}$} \\
\hline & & & $100 \mathrm{PCV}(\%)$ & \\
\hline 8 & $\begin{array}{l}\text { Differential Leukocyte } \\
\text { Count (DLC) }\end{array}$ & {$[54]$} & $\begin{array}{l}\text { Different cells were identified and } \\
\text { counted }\end{array}$ & $\%$ \\
\hline
\end{tabular}

\subsection{Statistical Analysis}

Values are expressed as Mean $\pm \mathrm{SD}$ and the results obtained were analyzed using one-way ANOVA. Inter group comparisons were performed by using the least significance difference (LSD) test. A probability value of $P$ $<0.05,0.01$ was considered as statistically significant.

\section{Results}

The alterations in various haematological parameters are presented in the table 3. Single dose administration of cadmium resulted in significant changes in the haematological parameters screened 20 and 40 days after the exposure.

Effect on TEC: There was a significant decrease $(\mathrm{P}<0.05)$ of about $33.79 \%$ in TEC in Cd-20 group and a significant decrease $(\mathrm{P}<0.01)$ of $53.03 \%$ after 40 days in $\mathrm{Cd}-40$ group as compared to the respective control values.

Effect on $\mathrm{Hb}$ : The $\mathrm{Hb}$ levels also decreased significantly $(\mathrm{P}<0.05)$ by a percentage of 22.43 and 35.10 in $\mathrm{Cd}-20$ and Cd-40 groups respectively as compared to control groups.

Effect on PCV: There was a significant decrease $(\mathrm{P}<0.05)$ of about $12.43 \%$ and $13.71 \%$ in PCV values in $\mathrm{Cd}-20$ and Cd-40 groups respectively as compared to control groups.
Effect on TLC: There was a significant increase $(\mathrm{P}<0.05)$ of about $21.38 \%$ in TLC count in Cd-20 group and a significant increase $(\mathrm{P}<0.01)$ of $39.89 \%$ after 40 days in Cd-40 group as compared to the respective control values.

Effect on MCV: The MCV values also increased significantly $(\mathrm{P}<0.01)$ by a percentage of 32.26 and 83.75 in $\mathrm{Cd}-20$ and $\mathrm{Cd}-40$ groups respectively as compared to control groups.

Effect on $M C H$ : The $\mathrm{MCH}$ values also increased significantly $(\mathrm{P}<0.05)$ by a percentage of 17.15 and 38.18 in $\mathrm{Cd}-20$ and $\mathrm{Cd}-40$ groups respectively as compared to control groups.

Effect on MCHC: The MCHC values also decreased non significantly by a percentage of 11.43 and decreased significantly $(\mathrm{P}<0.05)$ by $26.07 \%$ in $\mathrm{Cd}-20$ and $\mathrm{Cd}-40$ groups respectively as compared to control groups.

Effect on DLC: There was a significant decrease $(\mathrm{P}<0.01)$ in the neutrophils whereas eosinophils, monocytes, lymphocytes and basophils (non significant) were found to increase significantly in $\mathrm{Cd}-20$ and $\mathrm{Cd}-40$ groups respectively as compared to control groups. The \% decrease in neutrophils was 36.36 and 20 in the $\mathrm{Cd}-20$ and Cd-40 groups respectively. The \% increase in eosinophils, monocytes, lymphocytes and basophils in Cd-20 group was $125,150,80$ and 200 respectively in Cd-20 group and 115, $40,57.14$ and 100 respectively in Cd-20 group. 
Table 3. Table showing the various values of the parameters studied in the experimental groups. All the data are expressed as mean $\pm \mathrm{SD}$. $\mathrm{a}=\mathrm{compared}$ to control group 20 day; $\mathrm{b}=$ compared to control group 40 day; $* * \mathrm{P}<0.01,{ }^{*} \mathrm{P}<0.05$, NS= non-significant

\begin{tabular}{|c|c|c|c|c|c|}
\hline \multirow[b]{2}{*}{ S.No. } & \multirow[b]{2}{*}{ Parameters } & \multicolumn{2}{|c|}{$20 \mathrm{DAY}$} & \multicolumn{2}{|c|}{$40 \mathrm{DAY}$} \\
\hline & & $\begin{array}{l}\text { Control group } \\
(\mathrm{C}-20)\end{array}$ & $\begin{array}{l}\text { Cadmium treated group } \\
(\mathrm{Cd}-20)\end{array}$ & $\begin{array}{l}\text { Control group } \\
\text { (C-40) }\end{array}$ & $\begin{array}{l}\text { Cadmium treated } \\
\text { group }(\mathrm{Cd}-40)\end{array}$ \\
\hline 1 & TEC (million $/ \mathrm{mm}^{3}$ ) & $3.64 \pm 0.8945$ & $2.41 \pm 1.2154^{\mathrm{a}^{*}}$ & $3.94 \pm 0.03$ & $1.85 \pm 0.025^{\mathrm{b} * *}$ \\
\hline 2 & $\mathrm{Hb}(\mathrm{gm} / \mathrm{dl})$ & $11.50 \pm 0.7453$ & $8.92 \pm 0.6144^{\mathrm{a}^{*}}$ & $12.96 \pm 0.316$ & $8.41 \pm 0.019^{b^{*}}$ \\
\hline 3 & PCV (\%) & $34.50 \pm 0.5621$ & $30.21 \pm 0.4856^{\mathrm{a}^{*}}$ & $38.12 \pm 0.456$ & $32.89 \pm 0.327^{\mathrm{b}^{* *}}$ \\
\hline 4 & $\operatorname{TLC}\left(10^{3} / \mathrm{mm}^{3}\right)$ & $18000 \pm 122.125$ & $21850 \pm 123.136^{\mathrm{a}^{*}}$ & $18600 \pm 121.8$ & $25915 \pm 161.03^{b^{*}}$ \\
\hline 5 & $\operatorname{MCV}(\mathrm{Fl})$ & $94.78 \pm 2.2154$ & $125.36 \pm 2.784^{\mathrm{a}^{* *}}$ & $96.75 \pm 0.081$ & $177.78 \pm 2.747^{b^{* *}}$ \\
\hline 6 & $\mathrm{MCH}(\mathrm{pg})$ & $31.59 \pm 0.1276$ & $37.01 \pm 1.2554^{\mathrm{a}^{*}}$ & $32.89 \pm 0.046$ & $45.45 \pm 0.3742^{\mathrm{b}^{*}}$ \\
\hline 7 & $\mathrm{MCHC}(\mathrm{gm} / \mathrm{dl})$ & $33.33 \pm 1.8954$ & $29.52 \pm 1.2365^{\mathrm{aNS}}$ & $33.99 \pm 0.400$ & $25.57 \pm 0.244^{\mathrm{b}^{*}}$ \\
\hline 8 & Lymphocyte \% & $67 \pm 1.1426$ & $80 \pm 1.8451^{\mathrm{a}^{* *}}$ & $56 \pm 1.14$ & $88 \pm 0.5099^{\mathrm{b}^{* *}}$ \\
\hline 9 & Neutrophil \% & $22 \pm 0.9784$ & $14 \pm 0.865^{\mathrm{a}^{* *}}$ & $45 \pm 1.321$ & $36 \pm 0.7348^{\mathrm{b}^{* *}}$ \\
\hline 10 & Eosinophil \% & $4 \pm 0.2158$ & $9 \pm 0.2567^{\mathrm{a}^{*}}$ & $4 \pm 0.7071$ & $8.6 \pm 0.3742^{\mathrm{b}^{*}}$ \\
\hline 11 & Monocyte \% & $4 \pm 0.4856$ & $10 \pm 0.4715^{\mathrm{a}^{*}}$ & $5 \pm 0.337$ & $7 \pm 0.3742^{b^{*}}$ \\
\hline 12 & Basophil \% & $3 \pm 0.7453$ & $9 \pm 0.9442^{\mathrm{a}^{*}}$ & $1 \pm 0.2449$ & $2 \pm 0.3162^{\mathrm{bNS}}$ \\
\hline
\end{tabular}

\section{Discussion}

Exposure of Kuroiler chicks treated with cadmium acetate produced marked alteration in hematological parameters. The present study clearly shows significant decrease in TEC, $\mathrm{Hb}, \mathrm{PCV}, \mathrm{MCHC}$ and neutrophils and increase in TLC, $\mathrm{MCH}$ after 20 and 40 days post treatment. Decrease in TEC, PCV and $\mathrm{Hb}$ indicates anaemic condition of the chick as also reported earlier due to oral and intraperitoneal (i.p.) administration of cadmium [5, 55]. In the present study cadmium was administered orally after 10 days of hatching and the anaemic condition as well as the haematotoxic effect of cadmium treatment was evident even after 40 days of post treatment. The mechanism for cadmium induced anaemia though not clear but has been attributed to iron-deficiency due to inhibition of iron absorption from the gastrointestinal tract [56], hyperplastic anaemia derived from the inhibitory effect of cadmium on the growth of erythroid progenitor cells [23, 57]; haemolytic anaemia due to red blood sequestration in spleen [58] which results in shorter life span and increased destruction of erythrocytes in spleen and liver; hypo production of erythropoietin due to renal injury [59].

The decrease in MCHC and increase in MCV supports the view that iron deficiency contributes to the development of anaemia as also seen in cadmium treated mice [60].

Reduction in number of RBCs can be attributed to decreased rate of erythropoiesis [61] or loss of erythrocytes due to toxicant induced haemorrhage in the internal organs [62]. Decrease in $\mathrm{Hb}$ content, total erythrocyte count and PCV value under stressful condition could be an expected consequence of loss of erythrocyte.

Significant increase of WBC count in cadmium exposed groups indicates the hyper sensitivity of WBC to cadmium which might be due to immunological reaction to produce antibodies to cope up with stress induced by the toxicant. Increase in WBC count can be correlated with an increase in antibody production which helps in survival and recovery from the toxic effect of cadmium.

Decrease in the $\mathrm{Hb}$ content as observed might be attributed to the rapid oxidation of $\mathrm{Hb}$ to methahaemoglobin or release of $\mathrm{O}_{2}{ }^{-}$radical due to toxic stress of cadmium. Neutrophils were found to be decreased in treated groups. Eosinophils, Monocyte, lymphocytes and basophils were found to be increased in both treated groups as compared to the control group indicating the stressful status.

Haematological parameters have commonly been used as indicators of physiological conditions and nutritional deficiency in chickens. The changes in haemoglobin concentration, total erythrocyte count, haematocrit level and differential leukocyte count may indicate stress [63-64], while the changes in erythrocyte, haemoglobin and packed cell volume may reflect an alteration of energy status in chickens [65-66].

\section{Conclusions}

It is thus concluded that cadmium induced impairment of metabolism as chicks were observed to be under severe metabolic stress. The haematological alteration and variation in different enzymes can be used as good biomarkers of cadmium pollution in the terrestrial environment.

Further, research with toxicity testing method would give a more comprehensive picture which can be of great importance in monitoring the possible eco toxicological risk assessment of cadmium. 
Moreover, in the present study, even after 40 days of exposure to a single dose of cadmium, the values of different hematological parameters didn't show much improvement indicating that cadmium is not excreted out easily from the body and its effect are both time and age dependent.

Furthermore, it is also concluded that the anaemic condition, altered haematological profile and metabolic stress in Kuroiler chickens would definitely alter the quality of meat lowering the protein content as well as weakening the poultry economy.

\section{Acknowledgements}

The authors are thankful to Prof. S S Lal, Emeritus Professor, Department of Zoology, Ch. C. S. University, Meerut for his valuable guidance and motivation.

\section{REFERENCES}

[1] A. J. Alabi, J. W. Ng'ambi., E. F. Mbajiorgu, D. Norris and M. Mabelebele. Growth and haematological response of indigenous Venda chickens aged 8 to 13 weeks to varying dietary lysine to energy ratios. Journal of Animal Physiology and Animal Nutrition, 99, 436-441, 2015.

[2] M.A. Alodan, and M.M. Mashaly. Effect of induced molting in laying hens on production and immune parameters. Poultry Science, 78: 171-177, 1999.

[3] O.F. Al-Rawashdeh, A.Y. Gumaa, M. Saeed, J.I. Orban, J.A Patterson, and A.Y.M. Nour. Effects of sucrose thermal oligosaccharide carmel and feed restriction on performance, haematological values and ceacal bacteriological count of broiler chickens. Acta Veterinaria Beograd, 50: 225-239, 2000 .

[4] R.K. Archer, L.B. Jeffcott (Eds.). Comparative clinical haematology, Blackwell Scientific Publications, Oxford (1977), pp. 537-610, 1977

[5] D. Bagchi, P.J. Vuchetich, M. Bagchi, E.A. Hassoun, M.X. Tran, L. Tang, S.J. Stohs. Induction of oxidative stress by chronic administration of sodium dichromate and cadmium chloride to rats. Free Radical Biology and Medicine, 22: 471-478, 1997.

[6] R. Bajpai, D.K. Upreti. Accumulation and toxic effect of arsenic and other heavy metals in a contaminated area of West Bengal, India, in the lichen Pyxine cocoes (Sw.) Nyl. ecotoxicology and Environmental Safety. 83:63-70, 2012.

[7] J. Bokori. Occurrence of cadmium in the nature and its more important physiological characteristics (in Hungarian). Magy Állatorv Lapja. 49(2): 69-73, 1994.

[8] V.R. Borane. Protective role of ascorbic acid on the cadmium induced changes in hematology of the freshwater fish, Channa orientalis (Schneider). Advances in Applied Science Research. 4(2):305-308, 2013.
[9] S. A. Borges, A. V. Fischer da Silva, A. Majorka, D. M. Hooge, K.R. Cummings. Physiological responses of broiler chickens to heat stress and dietary electrolyte balance (sodium plus potassium minus chloride, milliequivalents per kilogram). Poultry Science, 83, 1551-1558, 2004.

[10] A.L. Calabrese, F.P. Thurberg, M.A. Dawson, D.R. Wenzloff. Sublethal physiological stress induced by cadmium and mercury in winter flounder Pseudopleuronectes americanus. In sublethal effect of toxic chemicals (eds.), J. H. Koeman J.J.T.W.A. Strik. Elsevier, Scientific Co. Amsterdam, 15-21, 1975.

[11] D. K. Chauhan, M. Irfan, P. Bajharia, J. Saini, P. Chauhan. Immunopathological alterations in thymus induced by cadmium acetate in kuroiler chicks. Journal of Natural Resource and Development. 13 (1) 99-104, 2018.

[12] I. Davidson, and J.B. Henry. Todd-Samford clinical diagnosis by laboratory method, 14th Edn., W.B. Saunders Co., Philadelphia, London, Toronto. pp. 139-143, 1969.

[13] G.N. Egbunike, E.A. Agiang, A.O. Owosibo, and A.A. Fafute. Effects of protein on performance and haematology of broilers fed cassava peel-based diets. Archivos de Zootecnia, 58: 224, p 656, 2009.

[14] D. J. Finney. Probit analysis: Statistical treatment of the sigmoid curve. London: Cambridge University Press, 1964.

[15] L. Friberg, C.G. Blinder, T. Kjellstrom, G.F. Nordberg. Cadmium and Health: A Toxicological and Epidemiological Appraisal. Vol. I. pp. 103-178. CRC Press, Boca Raton, Florida. 1986

[16] R.L. Furlan, M. Macari, R.D. Malherious, V.M.B. Moraes, E.B. Malherious. Effect of age and strain on haematology and blood biochemical parameters in broiler chickens. Revista Brasileira de Ciencia Avicola, 1: 77-84, 1999.

[17] N. Galip. The effect of restricted feeding on some blood parameters and live weight of turkeys. Vet. Fakult. Derg., Uludag Uni., 18: 149-158, 1999

[18] P.L. Goering, M.P. Waalkes, C.D. Klaassen. Toxicology of cadmium. In: R. A. Goyer and M.G. Cherian (Eds.) Toxicology of Metals: Biochemical Aspects. Handbook of Experimental Pharmacology, Vol. 115, pp. 189-213. Spinger-Verlag, New York. 1995.

[19] S. Graczyk, A. Pliszczak-Krol, B. Kotonski, J. Wilczek, Z. Chmielak. Examinations of haematological and metabolic changes mechanisms of acute stress in turkeys. Electronic J. Polish Agriculture University, Vet. Med., 6: 1-10, 2003.

[20] B.P Hardiker, K.S. Gokhale. Study of haematological parameters of sewage fed fish, Sarotherodon mossambicus (PETERS). Bulletin of Pure and Applied Sciences, 19A (1): 7-13. 2000.

[21] H. Imer, M. Bujar, H. Arben, and G. Izedin. Hematological Effects of Cadmium in Hybrid Isa brown. European Journal of Experimental Biology, 2012, 2 (6):2049-2054, 2012.

[22] O. Hiratsuka, O. Katsuta, N. Toyata, M. Tsuchitani, T. Umemura, F. Marumo. Chronic cadmium exposure induced renal anaemia in ovariectomized rats. Toxicology and Applied Pharmacology, 137: 228-236, 1996.

[23] H. Horiguchi, M. Sato, N. Konno, M. Fukushima. Long-term cadmium exposure induces anaemia in rats through 
hypoinduction of erytrhopoietin in the kidney. Archives of Toxicology, 71: 11-19, 1996.

[24] H. Horiguchi, H. Teranish, K. Niiya, K. Aoshima, T. Koth, N. Sakuragawa, M. Kasuya. Hypoproduction of erythropoietin contributes to anaemia in chronic cadmium intoxication: Clinical study on Itai-itai disease in Japan. Archives of Toxicology, 68: 632-636, 1994.

[25] P. Hrabcakova, E. Voslalova, I. Bedanova, V. Pistjkova, J. Chloupek V. Vecerek. Haematological and biochemical parameters during the laying period in common pheasant hens housed in enhanced cages. The Scientific World Journal, http://dx.doi.org/10.1155/2014/364602. 2014.

[26] V. Hymavathi, L.M. Rao. Effect of sublethal concentrations of lead on the haematology and biochemical constituents of Channa punctatus, Bulletin of Pure and Applied Sciences, 19A (1): $1-5,2000$.

[27] IFAD (2012). E-conference of the International Network for Family Poultry Development in collaboration with FAO and supported by the International Fund for Agricultural Development (IFAD) 28 May - 15 June 2012; Strategic interventions for Family Poultry What can be achieved through Research \& Development activitieshttp://www.fao.org/ag/againfo/themes/en/poultry/ home.htmlwww.infpd.net

[28] F.C. Iheukwumere, U. Herbert. Physiological responses of broiler chickens to quantitative water restrictions: Haematology and serum biochemistry. International Journal of Poultry Science. 2: 117-119, 2003.

[29] M. L. Johnson- Sjoberk, A. Larsson. The effect of Cadmium on the haematology and on the activity delta amino levulinic acid- dehydrates (ALAD) in blood and Haematopoietic tissue of Flounder Pleuronectes fossilis. L. Res. 17.191-204 Environmental Research, 17,191-204. 1978.

[30] A. Karadeniz, N. Simsek S. Cakir. Haematological effects of dietary L-carnitine supplementation in broiler chickens. Revue de médecine vétérinaire, 159, 437-443, 2008

[31] C. Kemp, and M. Kenny, Feeding the modern broiler for more. International Hatchery Practice, 17: 11-13. 2003.

[32] M.Z. Khan, J. Szarek, A. Koncicki A. Krasnodebska. Oral administration of monensin and lead to broiler chicks: effects on haematological and biochemical parameters. Acta Veterinaria Hungeria, 42: 111-20, 1994.

[33] K. Kostial, Cadmium. In: (Ed. Mertz, W.) Trace Elements in Human and Animal Nutrition. Academic Press, Inc., San Diego, Calif., 2: 319-337. 1986.

[34] M.M. Kostic, B. Ognjanovic, S. Dimitrijevic, R.V. Ziric, A. Stajn, G.L. Rosic, R.V. Zivkovic. Cadmium induced changes of antioxidant and metabolic status in red blood cells of rats: in vivo effects. European Journal of Haematology, 51: 86-92, 1993.

[35] I. Kral, and P. Suchy, Haematological studies in adolescent breeding cocks. Acta Vet. Brno, 69: 189- 194, 2000.

[36] M. Kunimoto, and T. Miura, Density increment and decreased survival of rat red blood cells induced by cadmium. Environmental Research., 39: 86-95, 1986.

[37] F. Kurtoglu, V. Kurtoglu, T. Celik, T. Keceri, M. Nizamlioglu, Effects of dietary boron supplementation on some biochemical parameters, peripheral blood lymphocytes, splenic plasma cells and bone characteristics of broiler chicks given diets with adequate or inadequate cholecalciferol (vitamin D3) content. British poultry Science, 46: 87-96. 2005.

[38] D. Lamosova, M. Macajova, M. Zeman, Effects of short-term fasting on selected physiological functions in adult male and female Japanese quail. Acta Veterinaria. Brno, 73: 9-16, 2004.

[39] A. Larsson, Some biochemical effects of cadmium on fish. In: Sublethal effect of toxic chemicals on aquatic animals. Elsevier, Amsterdam. The Netherlands. pp. 3-13, 1975.

[40] J.D. Lutton, N.G. Ibraham, M. Friedland, and R.D. Levere, The toxic effects of heavy metals on rat bone marrow in vitro erythropoiesis: protective role of haemin and zinc. Environmental. Research, 39: 86-95, 1984.

[41] D. Manca, A.C. Richard, H. van Tra, G. Chevalier, Relation between lipid peroxidation and inflammation in the pulmonary toxicity of cadmium. Archives of Toxicology, 68:364-369, 1994

[42] J. Masopust, In: Clinical Biochemistry (in Czech). Karolinum, Praque. pp.832. 2000.

[43] D.J. Mc Leay, Effect of ACTH on the pituitary inter-renal axis and abundance of white blood cell types in juvenile coho salmon Oncorhynchus kisutch. Genearl and Comparative Endocrinology, 21, 431-440, 1973.

[44] R. Mehta, R. G. Nambiar, Livestock Industrialization, Trade and Social - Health Environment Impact in Developing Countries: A Case Study of Indian Poultry Sectorle, (Mimeo) Phase I project report submitted to IFPRI, May 2002.

[45] S. Mol, Levels of heavy metals in canned bonito, sardines, and mackerel produced in Turkey. Biological Trace Element Research.;143(2):974-82, 2011.

[46] Mukherjee, Medical laboratory technology. Tata Mc Graw Hill Publishing Company Ltd., Vol. I, pp. 242-243, 1988.

[47] E.Z. Mushi, M.G. Binta, R.G. Chabo, R.T. Ndebele, Haematological studies on apparently healthy Tswana indigenous chickens (Gallus domesticus) around Gaborone, Botswana. INFPD News letter, 9: 83-88, 1999.

[48] S. Naziefy-Habibabadi, Haematology and Clinical Biochemistry of Birds. Shiraz University Press, No. 272, pp: 247-258. 1997.

[49] M. Noda, M. Yasuda, M. Kitagawa, Iron as a possible aggravating factor for osteopathy in Itai-itai disease, a disease associated with chronic cadmium intoxication. Journal of Bone Mineral Research, 6: 245-255, 1991.

[50] A.A. Odunsi, A.A. Onifade, G.M. Babatunde, Response of broiler chicks to virginiamycin and dietary protein concentrations in the humid tropics. Archives de Zootecnia., 48: 317-325, 1999.

[51] OSHA, Cadmium health effects. Occupational Safety and Health Administration US Department of Labor, 1999.

[52] D.C. Ramirez, M.S. Gimenez, Induction of redox changes, inducible nitric oxide synthase and cyclooxygenase- 2 by chronic cadmium exposure in mouse peritoneal macrophages. Toxicology Letters. 145:121-132, 2003. 
[53] RC (National Research Council): Cadmium. In: (Ed. NRC) Mineral tolerance of domestic animals. National Academy of Sciences, Washington, D.C., pp. 93-130. 1980.

[54] K.A. Saeed, M.A. Lakal, K. Obad, Changes in some biochemical parameters and body weight of chicken exposed to cadmium. World Journal of Pharmaceutical Research Volume 5, Issue 3, 227-234, 2016.

[55] T. Sahli, 1962. Text book of clinical pathology. (Ed: Scward, Eimiller). Williams and Willams and Co., Baltimore. pp. 35 (1966).

[56] S. Sakata, K. Iwami, Y. Enoki, H. Kohzuki, S. Shimizu, Effects of cadmium on in vitro and in vivo erythropoiesis: erythroid progenitor cells (CFU-E), iron erythropoietin in cadmium-induced iron deficiency anaemia Exp. Haematoi., 16: 581-587, 1988.

[57] S.G. Schaefer, B. Elsenhans, Iron retention and distribution in the cadmium induced iron deficiency. Ecotoxicology and Environmental Safety, 10: 128-141, 1985.

[58] P.E. Seiser, L.K. Duffy, D. McGuire, D.D. Roby, G.H. Golet, M.A. Litzow, Comparison of pigeon guillemot, Cepphus columba, blood parameters from oiled and un-oiled areas of Alaska eight years after the Exxon Valdez oil spill. Marie Pollution Bulletin, 40: 152-164, 2000.

[59] Z.A. Shaikh, T.T. Vu, K, Zaman, Oxidative stress as a mechanism of chronic cadmium-induced hepatotoxicity and renal toxicity and protection by antioxidants. Toxicology and Applied Pharmacology, 154:256-263, 1999.

[60] M. Trzcinka-Ochocka, M. Jakubowski, W. Szymczak, B. Janasik, R. Brodzka, The effects of low environmental cadmium exposure on bone density. Environmental Resarch, 110(3):286-93, 2010.

[61] A. Tyagi, Effect of Cadmium Acetate on ImmunoHematological Parameters in White Leg-Horn Chicks. International Archive of Applied Sciences and Technology IAAST; Vol 3 [4] December 2012: 40-42, 2012.

[62] B.L. Vallee, and D. D. Ulmer, Biochemical Effects of Mercury, Cadmium, and Lead. Annual Review of Biochemistry Vol. 41:91-128, 1972.

[63] R. Van Bruwaene, R. Kirchmann, R. Impens, Cadmium contamination in agriculture and zootechnology. Experientia 40, 43-52, 1984.

[64] V. Vecerek, E. Strakova, P. Suchy and E. Voslarova, Influence of high environmental temperature on production and haematological and biochemical indexes in broiler chickens. Czech Journal of Animal Science, 47: 176-182, 2002.

[65] M. Waisberg, P. Joseph, B. Hale, D. Beyersmann, Molecular and cellular mechanisms of cadmium carcinogenesis. Toxicology. 192:95-117, 2003.

[66] WHO 1963. Technical report series. No.842 (Expert committee on medical assessment and nutritional status). WHO, Geneva.

[67] Q. Zaman, M.Z. Khan, N. Islam, G. Muhammad, Experimental furazolidone toxicosis in broiler chicks: effect of dosage, duration and age upon clinical signs and some blood parameters. Acta Veterinaria Hungaria, 43: 359-67. 1995. 